\title{
Zmiany struktury przestrzennej obszaru Zabłocia w Krakowie objętego lokalnym programem rewitalizacji
}

Planowanie przestrzenne według A. Jędraszki (2005) jest główną płaszczyzną, na której następuje konfrontacja resortowych planów i zamierzeń nawiązujących do zagospodarowania i rozwoju przestrzennego państwa, a w wypadku niniejszego artykułu - rewitalizowanego obszaru Zabłocia oraz obszarów przyległych, a w dalszj kolejności całego miasta. Stąd opracowywane obecnie Lokalne Programy Rewitalizacji (LPR) w wielu miastach Polski powinny być zgodne z polityką przestrzenną gminy, mając na uwadze to, iż obszar obejmowany LPR powinien być również w pierwszej kolejności objęty Miejscowym Planem Zagospodarowania Przestrzennego (MPZP) i być z nim skoordynowany (Podręcznik rewitalizacji 2003). Należy tutaj dodać, iż taki plan działań został zrealizowany na poprzemysłowym obszarze Zabłocia w Krakowie. W pierwszej kolejności został uchwalony MPZP w czerwcu 2006, a następnie w październiku 2006 r. LPR zgodny z MPZP.

W świetle powyższych przesłanek celem pracy będzie analiza zmian struktury przestrzennej obszaru Zabłocia objętego MPZP i LPR w ostatnich pięciu latach. Jest to kontynuacja wcześniej rozpoczętych badań (Świerczewska-Pietras 2010 a,b; Rachwał, ŚwierczewskaPietras 2010; Świerczewska-Pietras 2009 a,b).

\section{ISTOTA REWITALIZACJI W ASPEKCIE PRZESTRZENNYM}

Jedna z najnowszych definicji rewitalizacji (formułowana przez Komitet Naukowy, w skład którego wchodzą m.in. przedstawiciele Instytutu Rozwoju Miast, opracowujący projekt badawczy pt. „Rewitalizacja miast polskich jako sposób zachowania dziedzictwa materialnego i duchowego oraz czynnik zrównoważonego rozwoju”) zakłada, iż rewitalizacja „to skoordynowany proces, prowadzony wspólnie przez władzę samorządową, społeczność lokalną i innych uczestników, będący elementem polityki rozwoju i mający na celu przeciwdziałanie degradacji przestrzeni zurbanizowanej i zjawiskom kryzysowym, pobudzanie rozwoju i zmian jakościowych poprzez wzrost aktywności społecznej i gospodarczej, poprawę środowiska zamieszkania oraz ochronę dziedzictwa narodowego, przy zachowaniu zasad zrównoważonego rozwoju" (Janas, Jarczewski 2010). Według Z. Ziobrowskiego (2010) stosowanie zasady zrównoważonego rozwoju w kształtowaniu procesu rewitalizacji jest niezbędne $\mathrm{z}$ uwagi na holistyczne rozwiązania istniejących potrzeb. Zrównoważone podejście 
do wdrażania działań rewitalizacyjnych wymaga połączenia wielu różnorodnych sfer składających się na funkcjonowanie miasta, jak m.in.:

- sferę społeczną-zmiany w sferze dokonują się poprzez zmiany jakości warunków życia mieszkańców,

- sferę ekologiczą - zmiany dokonują się poprzez poprawę jakości środowiska przyrodniczego,

- sferę prawną - w której ustala się ramy prawne dla tworzenia i wdrażania procesów rewitalizacyjnych,

- sferę finansową - która określa instrumenty wsparcia dla działań rewitalizacyjnych,

- sferę gospodarczą - pobudzającą aktywność gospodarczą obszarów,

- sferę planistyczno-przestrzenną - odpowiedzialną za kształtowanie przestrzeni miejskiej, przy wykorzystaniu istniejącej tkanki bądź nadaniu nowej funkcji przy zmianie charakteru obszaru. Na potrzeby niniejszej pracy poddano analizie sferę planistyczno-przestrzenną obszaru Zabłocia.

Warto również zaakcentować przyjętą w 2009 r. w Poznaniu na 3 Kongresie Urbanistyki Kartę Przestrzeni Publicznej, w której urbaniści apelują do władz miasta, środowisk naukowych oraz społeczeństwa, aby traktowali oni przestrzeń publiczną jako najwyższą wartość, decydującą o tożsamości miasta. W Karcie określono, iż dbanie o przestrzeń publiczną musi stać się niekwestionowanym prawem i obowiązkiem obywatelskim. W Karcie również wskazano osiem zasad organizowania i użytkowania przestrzeni publicznych, do których zaliczają się (Markowski 2009, s. 36):

- zasada maksymalizacji wartości miasta i jego nieruchomości poprzez kreowanie wysokiej jakości przestrzeni publicznych;

- kompleksowe planowanie miejscowe oraz projektowanie urbanistyczne przestrzeni publicznych w oparciu o wyniki konkursów urbanistycznych i architektonicznych;

- społeczna partycypacja w tworzeniu narzędzi kształtowania i gospodarowania przestrzenią publiczną, z aktywnym udziałem lokalnych społeczności w procesie sporządzania dokumentów planistycznych;

- ochrona dziedzictwa kulturowego oraz specyfiki lokalnej jako szczególnych wartości przestrzeni publicznych;

- równowaga w tworzeniu nowej przestrzeni publicznej w stosunku do rewitalizowanej przestrzeni historycznej;

- sprawiedliwy dostęp do przestrzeni publicznych i minimalizacja konfliktów przy ich tworzeniu oraz użytkowaniu;

- kształtowanie przestrzeni publicznych integrujących grupy społeczne z szacunkiem dla ich różnych potrzeb i systemów wartości;

- aktywne użytkowanie przestrzeni publicznych i ich wykorzystywanie do organizowania wydarzeń lokalnych.

Według S. Gzella (2006), aby rewitalizacja i planowanie w Polsce przebiegały na najwyższym poziomie należy sporządzać analizy dotyczące:

- stanu planowania - analiza rozpoczętych i uchwalonych MPZP;

• „podaży planistycznej”, do której zalicza się chłonność terenów dla nowych inwestycji;

- popytu inwestycyjnego;

- planistycznego scalania miasta;

- zarządzania rozwojem miasta w przyszłości.

Ponadto najważniejsze jest ustalenie sekwencji działań, które doprowadzą do osiągnięcia zamierzonego rezultatu przestrzennego. 


\section{CHARAKTERYSTYKA OBSZARU}

Zabłocie to poprzemysłowy obszar obejmujący zgodnie z granicami MPZP 175 ha, znajdujący się w południowo-wschodniej części Krakowa. Pierwsza wzmianka o Zabłociu pojawiła się w I połowie XIV w., kiedy to obszar stanowił własność królewską. Kolejno w 1357 r. Kazimierz Wielki odsprzedał wieś Zabłocie miastu Kazimierz. Wiek XVII i XVIII przyniosły zniszczenia obszaru na skutek pożarów, kontrybucji wojskowych, powodzi oraz rabunków. Zabłocie swój poprzemysłowy charakter zawdzięcza lokalizacji w XIV w. portu i składu solnego, a także rozwijających się na przełomie XIX i XX w. fabryk i mniejszych zakładów produkcyjnych. Do najważniejszych można zaliczyć m.in. powstałą w 1949 r. fabrykę słodyczy i wyrobów cukierniczych (obecnie „Wawel”), fabrykę zapałek „Znicz”, na miejscu której powstała Huta Szkła w Krakowie, produkująca butelki na potrzeby Państwowego Monopolu Spirytusowego (obecnie po przekształceniach Instytut Szkła i Ceramiki), fabrykę dachówek azbestowych „Evaritas”, czy najbardziej znaną fabrykę naczyń emaliowanych i wyrobów blaszanych „Rekord”, która produkowała sprzęt na potrzeby armii niemieckiej. $\mathrm{Na}$ obszarze Zabłocia mieściła się również fabryka mydła, przekształcona w latach 50. XX w. w Krakowską Fabrykę Kosmetyków „Miraculum”, jak również garbarnia „Progress”. Od połowy lat 60 . do początku lat 80 . obszar Zabłocia poddawany był intensywnym przekształceniom. Wówczas to powstały największe zakłady produkcyjne w tym rejonie, m.in. Telpod. Zapoczątkowany w latach 90. ubiegłego wieku okres stagnacji gospodarczej na obszarze Zabłocia spowodowany przejściem z gospodarki centralnie sterowanej do wolnorynkowej spowodował upadek firm i przedsiębiorstw. Podstawowym problemem obszaru stała się powolna degradacja pomimo niewielkiej odległości od centrum miasta. Proces transformacji ekonomicznej dotknął znaczną część zakładów produkcyjnych Zabłocia, doprowadził do ich upadku, co znacząco wpłynęło na sferę społeczną poprzez likwidację miejsc pracy.

W wyniku pogłębiającego się kryzysu związanego z brakiem perspektyw na zmianę charakteru dzielnicy, władze miasta w pierwszej kolejności przystapiły do prac związanych z włączeniem zdegradowanego obszaru Zabłocia w strukturę miasta poprzez oddanie do użytku w 2002 r. Mostu Kotlarskiego, stanowiącego główną oś Trasy Centralnej komunikującą Zabłocie ze śródmieściem oraz południowymi dzielnicami mieszkaniowymi Krakowa. Następnie Gmina Miejska Kraków przystąpiła do prac zmierzających do przygotowania miejscowego planu zagospodarowania przestrzennego (MPZP), uchwalonego w czerwcu 2006 r., jak również lokalnego programu rewitalizacji (LPR), uchwalonego w październiku $2006 \mathrm{r}$.

W dokumencie MPZP i LPR granice obszaru zostały zawarte w obrębie ulic Stoczniowców, Nowohuckiej,Powstańców Wielkopolskich, Wielickiej,BolesławaLimanowskiego, Rękawka, Krakusa, Nadwiślańskiej oraz Na Zjeździe. Od północy na całej długości obszar graniczy z rzeką Wisłą. Zarówno w MPZP jak i w LPR Zabłocia został przyjęty trójpodział obszaru na część Zachodnią (w planie miejscowym część Starego Podgórza określona jako obszar „A” - koncentracja funkcji mieszkaniowej z wbudowanymi funkcjami usługowymi; typowy obszar śródmiejski o znacznym stopniu zdegradowania), część Centralną (Zabłocie przemysłowe wyznaczone dawnym przebiegiem linii kolejowych, w planie określone jako część „B”) oraz część Wschodnią (w planie miejscowym obszar „C” - użytkowany na różny sposób: przez przemysł, jako teren wystawienniczy, ogrody działkowe). Tym samym 


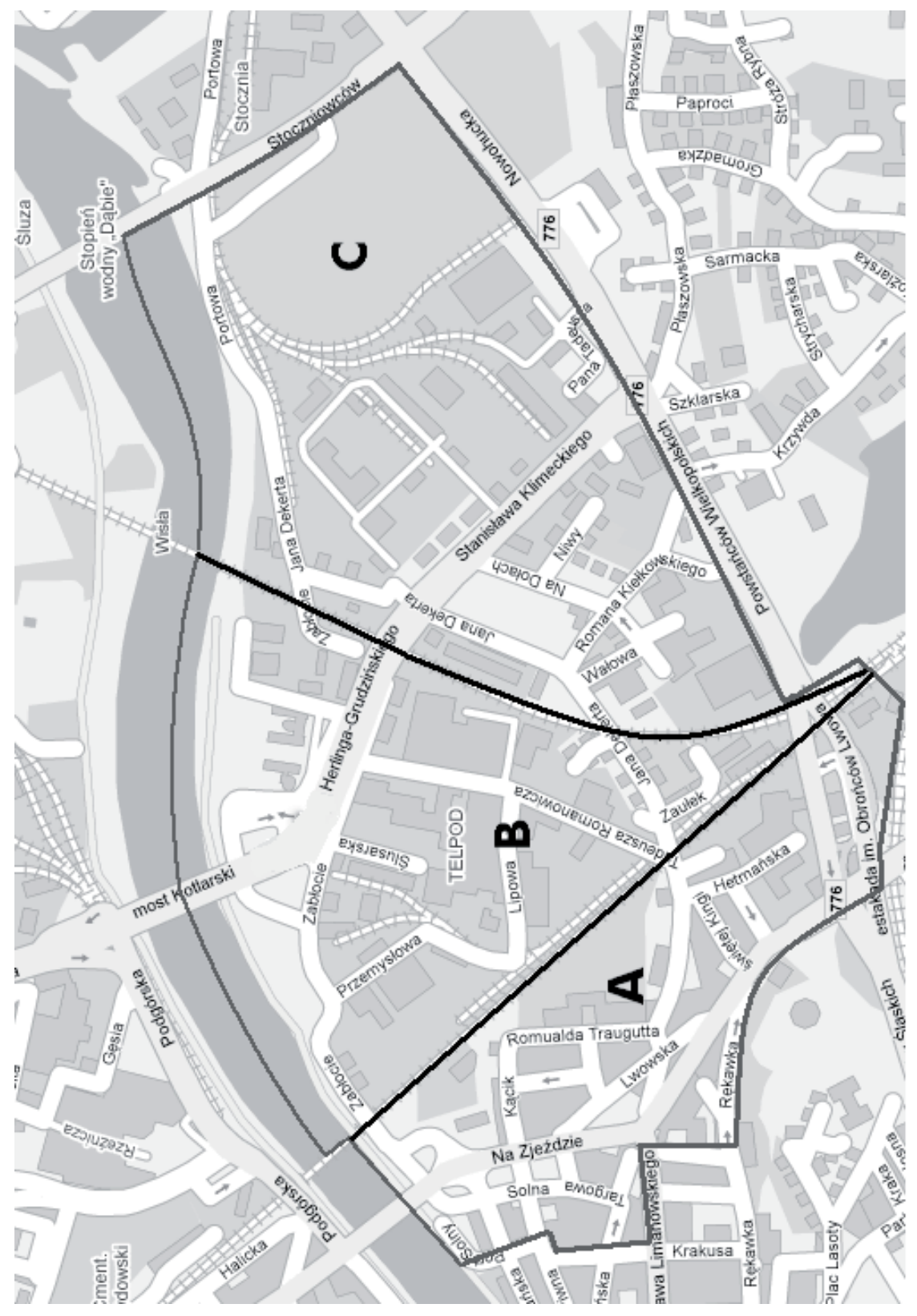

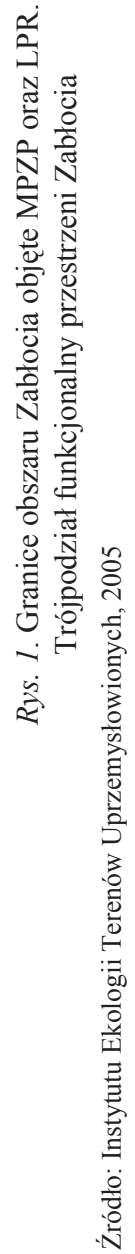


ustalone zostały wewnętrzne granice delimitacji obszarów kryzysowych, charakteryzujących się odmienną specyfiką funkcji i zagospodarowania przestrzennego oraz występujących tam problemów. W wyniku konsultacji i prac warsztatowych wypracowano trzy główne kierunki planowanych działań nawiązujące do podziału na sfery: przestrzenną, ekonomiczną i społeczną.

\section{Procesy REWITALIZACYJNE W STRUKTURZE PRZESTRZENNEJ OBSZARU}

Przywrócenie zdolności Zabłocia do samodzielnego funkcjonowania w strukturze Krakowa jest o tyle istotne, ponieważ obszar ten stanowi strategiczne położenie w funkcjonalno-przestrzennym układzie miasta. Przez teren Zabłocia przebiegają m.in. dwie linie kolejowe ruchu osobowego i towarowego, obsługujące ruch krajowy na trasie Tarnów, Zakopane, Bielsko-Biała, oraz ruch międzynarodowy na trasie średnicowej magistrali europejskiej E30 w kierunku Rzeszów, Lwów, Kijów. Ponadto przez obszar przebiega Trasa Centralna, która łączy południowe dzielnice mieszkaniowe z obszarem śródmieścia oraz z drogą wylotową w kierunku Warszawy (LPR Zabłocia, 2008). Obecnie na obszarze wybudowano linię Krakowskiego Szybkiego Tramwaju (KST) na trasie Rondo GrzegórzeckieGolikówka, przebiegającą przez Most Kotlarski i ul. Herlinga-Grudzińskiego w kierunku Płaszowa. Koszty budowy linii o długości 4,2 km przekroczyły $154 \mathrm{mln}$ zł. Przystanek KST na obszarze Zabłocia znajduje się na wysokości Krakowskiej Akademii im. Andrzeja Frycza Modrzewskiego (KA).

Na potrzeby zmiany charakteru dzielnicy w LPR Zabłocia zostały zawarte propozycje projektów wpływających na sferę przestrzenną. Autorzy zaproponowali jako projekt pilotażowy utworzenie Alei Lipowej, która przebiegając przez cały obszar Zabłocia jednocześnie pełniłaby funkcję głównego traktu dzielnicy. Z uwagi na usytuowanie na szlaku Muzeum Pamięci Miejsca w Fabryce Schindlera, jak również placu Bohaterów Getta, aleja pełniłaby funkcję kulturalno-edukacyjną, zmieniając charakter poprzemysłowego obszaru. Początek alei wyznacza plac Bohaterów Getta, kolejno aleja ma przebiegać przez ul. Kącik, przystanek Kraków-Zabłocie, ul. Romanowicza do ul. Powstańców Wielkopolskich. Jednakże miasto przystępując do remontu musi stworzyć spójną wizję i rozwiązanie urbanistyczno-architektoniczne, tak aby remont nie zakończył się jedynie na wymianie nawierzchni i chodników. W budżecie na 2010 r. nie uwzględniono środków na przebudowę ul. Lipowej, środki zapisano natomiast w budżecie na 2008 r. w kwocie 300 tys. zł, jednak zostały one przesunięte na realizację innych inwestycji. W LPR Zabłocia oszacowano orientacyjny koszt przebudowy ulicy wynoszący ponad $20 \mathrm{mln}$ zł. Przy trakcie alei wyremontowana i przebudowana została dawna fabryka Oskara Schindlera na funkcje kulturowe. Mieści w sobie Muzeum Historyczne Miasta Krakowa oraz wybudowane Muzeum Sztuki Współczesnej. Łącznie obiekt składa się z 11 budynków tworzących 10 tys. $\mathrm{m}^{2}$ powierzchni. Koszt inwestycji to ponad $71 \mathrm{mln}$ zł. Inwestycja otrzymała dotację ze środków Ministerstwa Kultury i Dziedzictwa Narodowego w kwocie $4 \mathrm{mln}$ zł oraz z Małopolskiego Regionalnego Programu Operacyjnego na lata 2007-2013 (MRPO 2007-2013) w kwocie $36 \mathrm{mln}$ zł. Na projekt Muzeum Sztuki Współczesnej został ogłoszony konkurs, który rozstrzygnięto w 2007 r. Zwyciężyła pracownia Claudio Nardi Architette. 


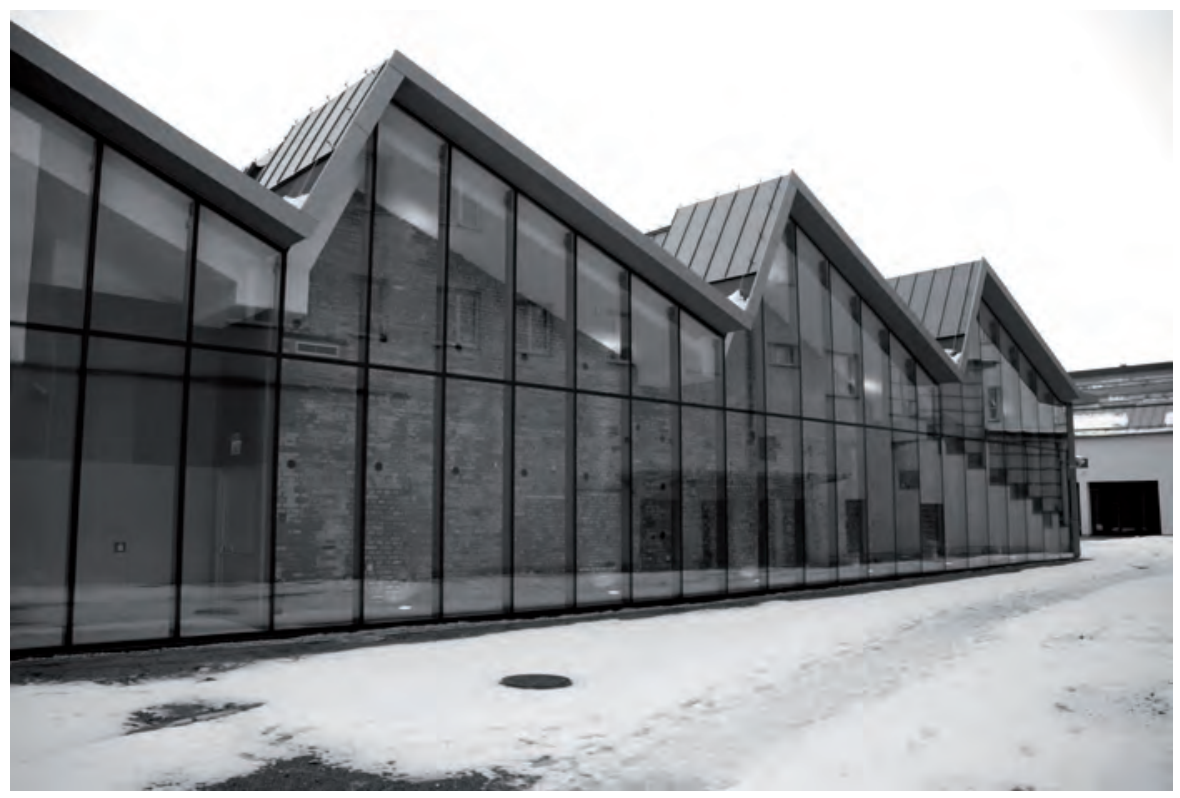

Fot. 1. Muzeum Sztuki Współczesnej

Autor: Katarzyna Świerczewska-Pietras, 2010

Można stwierdzić, iż ulica Lipowa po przekształceniu w aleję będzie mogła pełnić funkcję osi aktywizującej życie społeczne i ekonomiczne dzielnicy. Łączyć będzie ważne wątki historyczne z nowymi funkcjami i aspiracjami mieszkańców Zabłocia oraz kreować nową atrakcyjną przestrzeń publiczną.

Ponadto przestrzennym celem procesu rewitalizacji Zabłocia jest zwrócenie obszaru w stronę Wisły. Ma się do tego przyczynić opracowywany obecnie w Urzędzie Miasta Krakowa (UMK) MPZP „Bulwary Wiślane”, obejmujący obszar pomiędzy Mostem Powstańców Śląskich i Mostem Kotlarskim w kierunku Stopnia Wodnego Dąbie. Ważną inwestycją powstałą w pobliżu badanego obszaru Zabłocia jest kładka pieszo-rowerowa przez Wisłę w ciągu ulic Mostowej i Brodzińskiego. Kładka stanowi cześć projektu flagowego LPR Stare Miasto i ma przyczynić się do zwiększenia dostępności komunikacyjnej dwóch obszarów objętych programami rewitalizacji, tj. LPR Stare Miasto i LPR Zabłocia. Koszt budowy kładki to ponad $38 \mathrm{mln}$ zł, z czego $15 \mathrm{mln}$ zł pochodzi z dofinansowania unijnego w ramach działania 6.1 MRPO 2007-2013 przeznaczonego na projekty rewitalizacyjne. Planowana jest również budowa kładki Grzegórzki-Zabłocie, której inwestorem byłoby Miasto Kraków. Jednak do dnia dzisiejszego nie ma zapisów w budżecie miasta na ten cel.

Pierwsze efekty przekształceń przestrzennych obszaru można dostrzec w przebudowie placu Bohaterów Getta (dawnego placu Zgody) pomiędzy ul. Na Zjeździe, Targową, Solną i Piwną według zwycięskiej koncepcji ogłoszonego przez Gminę Miejską Kraków (GMK) konkursu architektoniczno-przestrzennego zagospodarowania terenu placu wraz z zabudową ${ }^{1}$. Plac przed przebudową pełnił funkcję parkingu dla autobusów oraz taksówek. Dominującym elementem placu oddanym w grudniu 2005 r. po remoncie są 33 wysokie

\footnotetext{
${ }^{1}$ Konkurs wygrało krakowskie biuro architektoniczne Lewicki\&Łatak, realizacja została powierzona konsorcjum firm Budostal 5/RDM.
} 
krzesła $^{2}$ rzeźbiarskie z lampą oraz 37 krzeseł rzeźbiarskich bez lampy. Dodatkowo plac od strony zachodniej i północnej uzupełniono szpalerem klonów kulistych. W zakres rzeczowy prac włączono również przebudowę dworca autobusowego oraz remont istniejącego przejścia podziemnego dla pieszych. Całość inwestycji kosztowała ponad $12 \mathrm{mln}$ zł. W 2006 r. projekt został wyróżniony w prestiżowym konkursie European Prize for Urban Public Space ${ }^{3}$.

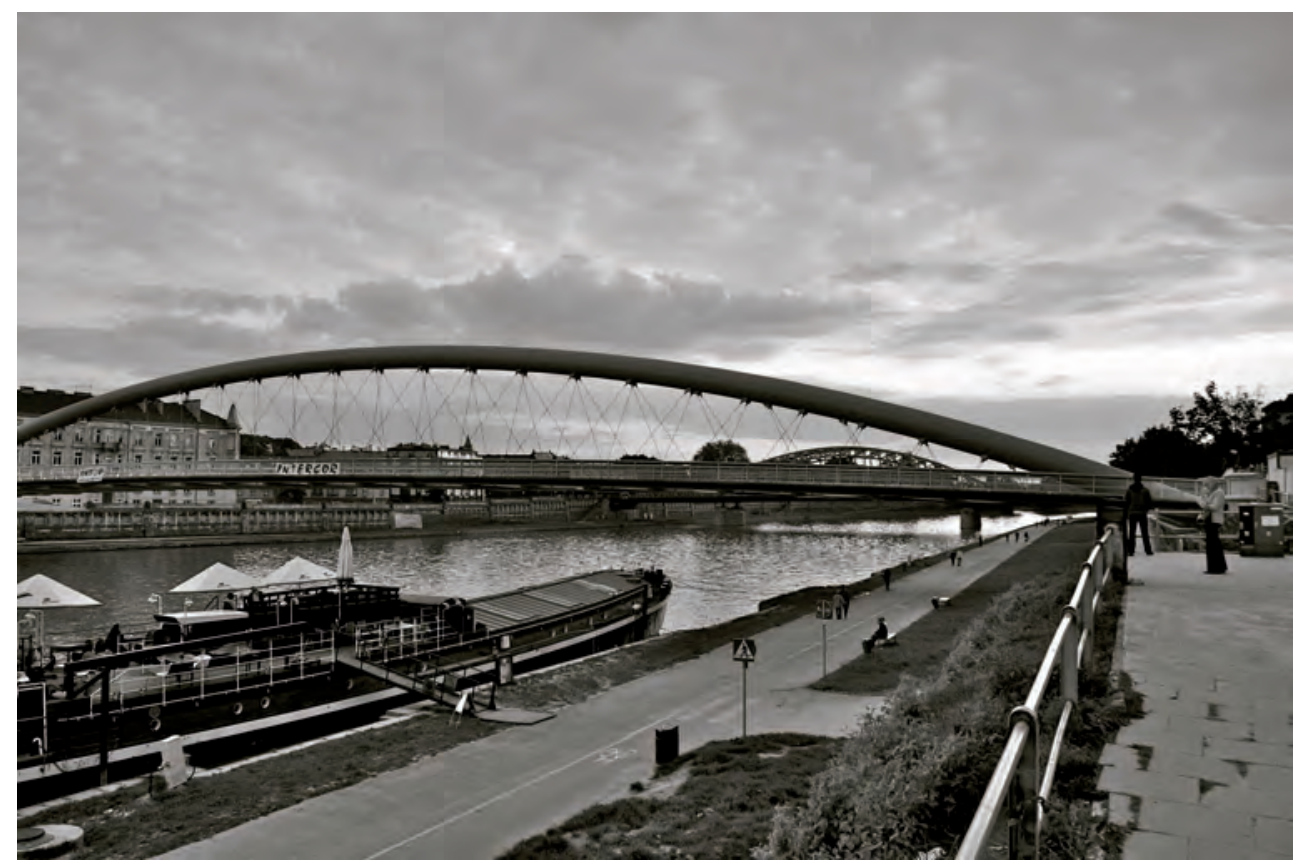

Fot. 2. Kładka pieszo-rowerowa przez Wisłę

Autor: Katarzyna Świerczewska-Pietras, 2010

W 2006 r. w sąsiedztwie placu Bohaterów Getta oddano do użytku czterogwiazdkowy hotel Cubus z 194 pokojami, restauracja, pubem, zespołem rekreacyjnym, zespołem handlowym, centrum konferencyjnym o łącznej powierzchni przekraczającej $500 \mathrm{~m}^{2}$ oraz parkingiem podziemnym. Powierzchnia całego obiektu wynosi $12002 \mathrm{~m}^{2}$, a jego kubatura $46095 \mathrm{~m}^{3}$. Generalnym wykonawcą hotelu była firma Hochtief Polska Oddział KpisCracovia.

${ }^{2}$ Krzesła symbolizują wyrzucane z domów krakowskich Żydów meble. Inspiracją dla projektu były wspomnienia Tadeusza Pankiewicza w książce Apteka w gettcie krakowskim, który opisywał plac podczas akcji opróżniania domów po ostatnich mieszkańcach getta.

${ }^{3}$ European Prize for Urban Public Space to nagroda utworzona w 2000 r., mająca na celu podkreślenie znaczenia przestrzeni publicznej jako katalizatora życia w mieście. Konkurs wyłaniający najlepsze przestrzenie publiczne jest organizowany co dwa lata przez sześć europejskich instytucji, Centre de Cultura Contemporínia de Barcelona, Cité de l'Architecture et du Patrimoine (Paryż), Architecture Foundation (London), Nederlands Architectuurinstituut (Rotterdam), Wien Architekturzentrum (Wiedeń) i Muzeum Architektury Finlandii (Helsinki). 


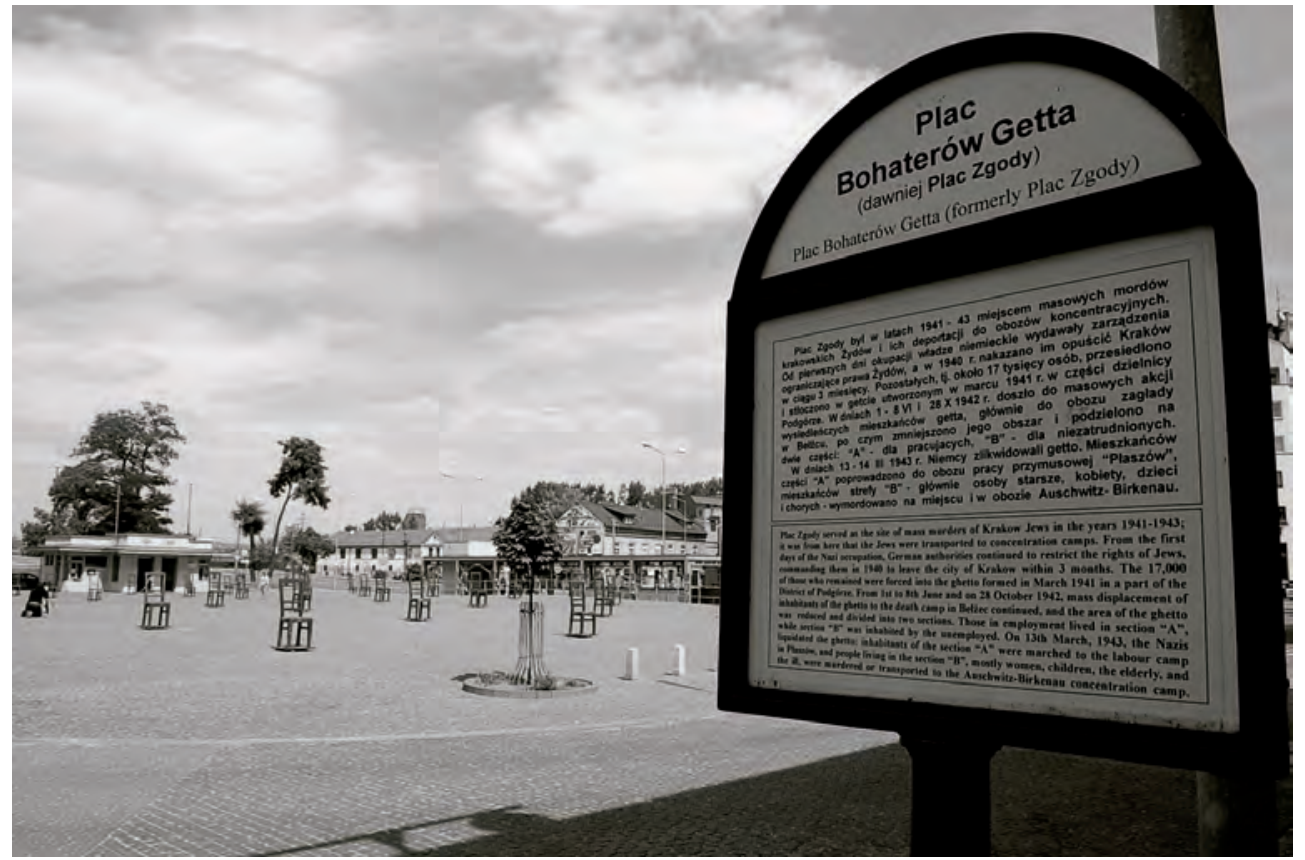

Fot. 3. Plac Bohaterów Getta

Autor: Katarzyna Świerczewska-Pietras, 2008

W pobliżu hotelu powstaje obecnie Muzeum Tadeusza Kantora - Cricoteka przy ul. Nadwiślańskiej w dawnym budynku elektrowni podgórskiej. Koszt inwestycji to ok. 29 mln zł. Jej zakończenie planowane jest na 2013 r. Inwestorem jest Małopolski Samorząd Wojewódzki.

W 2010 r. została ponadto wyremontowana ul. Przemysłowa, przy której znajduje się kompleks mieszkaniowy Garden Residence. Inwestycja ta została w pełni sfinansowana przez prywatnego inwestora, firmę Alpha Kraków Development Sp. z o.o. Z informacji uzyskanych z UMK wynika, iż miasto zaoszczędziło dzięki temu 500 tys. zł. W 2010 r. ten sam inwestor wyremontował przystanek PKP Zabłocie oraz przejście podziemne. Odmalowano barierki, wiaty dla pasażerów, słupy oświetleniowe, posprzątane zostały perony i odświeżone oznaczenia pasów na przystanku. W 2009 r. na obszarze Zabłocia przy ul. Dekerta zakończona została budowa biurowca Diamante Plaza oferującego 10 tys. $\mathrm{m}^{2}$ powierzchni biurowej klasy A. Koszt inwestycji to ponad 50 mln zł. Inwestorem jest Aldesa Polska. W 2010 r. obiekt ten otrzymał III nagrodę w konkursie Polskiego Związku Inżynierów i Techników Budownictwa.

$\mathrm{Na}$ obszarze Zabłocia planowana jest również budowa centrum biurowego Enterprise Park i Astrum (ich łączna powierzchnia to ponad 50 tys. $\mathrm{m}^{2}$ ) pomiędzy ul. Na Dołach i al. Powstańców Wielkopolskich. Koszt inwestycji to ponad $60 \mathrm{mln}$ euro. 


\section{SFERA MIESZKANIOWA OBSZARU ZABŁOCIA}

Zabłocie z uwagi na swój poprzemysłowy charakter cechuje się niskim poziomem zasobu mieszkaniowego i tym samym zaludnienia. Zgodnie ze stanem na koniec $2008 \mathrm{r}$. mieszkało tam ponad 4 tys. osób, w tym ponad 2 tys. kobiet. Najwięcej osób mieszkało w obszarze A, 84\% ludności całego obszaru, 11\% w obszarze C oraz najmniej w obszarze B - tylko 5\% (LPR Zabłocia, 2008). Liczba ta zmieni się obecnie dzięki nowym inwestycjom mieszkaniowym na obszarze Zabłocia, szczególnie w najmniej zaludnionej części B.

W 2010 r. został oddany do użytku największy obecnie kompleks mieszkaniowy na Zabłociu - Garden Residence, powstały na miejscu dawnego magazynu fabryki „Miraculum”. Jego powierzchnia wynosi ok. 65 tys. $\mathrm{m}^{2}$, w tym powierzchnia mieszkalna 27 tys. $\mathrm{m}^{2}$, powierzchnia usługowo-handlowa 5 tys. $\mathrm{m}^{2}$, powierzchnia garaży podziemnych i pomieszczeń technicznych ok. 30 tys. $\mathrm{m}^{2}$. Szacunkowa wartość inwestycji to $150 \mathrm{mln}$ zł. Kompleks składa się z 455 mieszkań, parkingu na 512 miejsc oraz części rekreacyjnej z fitnessem i basenem.

Przy ul. Przemysłowej 15 prowadzona jest kolejna inwestycja mieszkaniowa, którą realizuje Orion Investment S.A. Budynek będzie składał się z ośmiu pięter, lokali usługowych, 79 mieszkań o metrażach od 36,7 do $145,1 \mathrm{~m}^{2}$. Zakończenie inwestycji planowane jest na $2011 \mathrm{r}$.

W 2010 r. zostały oddane do użytku pierwsze w Krakowie lofty ${ }^{4}$ w dawnym młynie „Ziarno 2” przy ul. Zabłocie 25 (łącznie 57 mieszkań). Wartość inwestycji to ponad $50 \mathrm{mln}$ zł. Początkowo młyn miał zostać przekształcony na Centrum Przemysłu Czasu Wolnego, z basenem do głębokiego nurkowania o powierzchni $192 \mathrm{~m}^{2}$, salami gimnastycznymi, hotelem. Jednak jego ówczesny właściciel, Spółka Ziarno, odsprzedała budynek polsko-angielskemu inwestorowi - Kraków Lofts, który zrealizował inwestycję.

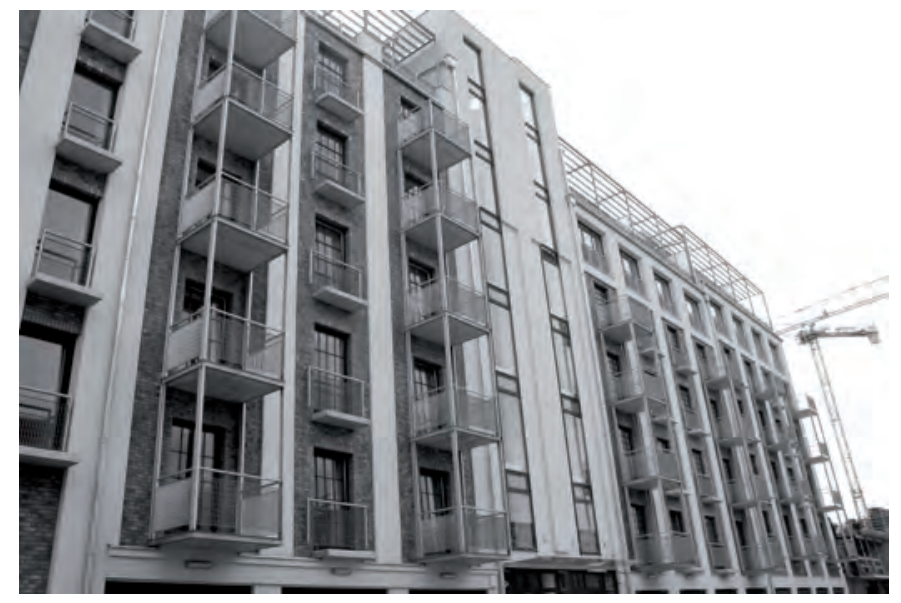

Fot. 4. Budynek dawnego młyna „Ziarno 2” przekształcony na lofty

Autor: Katarzyna Świerczewska-Pietras, 2010

${ }^{4}$ Pierwszy w Polsce loft o nazwie Bolko Loft mh1 powstał w Bytomiu w latach 2002-2003 w lampiarni dawnych zakładów Górniczo-Hutniczych „Orzeł Biały” w Bytomiu. Pomysłodawcą i realizatorem projektu był Przemo Łukasik z biura architektonicznego Medusa Group Architects. W 2006 r. Bolko Loft mh1 został uznany za jedną z 20 najciekawszych realizacji architektonicznych w Polsce po 1989 r. w konkursie „Polska ikona architektury”. 
Analiza obszaru pozwala ponadto stwierdzić, iż proces rewitlizacji zapoczątkowany przez remont placu Bohaterów Getta przyczynił się do zmian w otoczeniu. W 2007 r. został oddany do użytku apartamentowiec Wisła Residence przy ul. Piwnej 24, z 65 mieszkaniami i 6 lokalami usługowymi. W 2009 została oddana do użytku Villa Wisła przy placu Bohaterów Getta, wybudowana w sąsiedztwie apteki Pod Orłem (obecnie Muzeum Historycznego Miasta Krakowa) z 30 mieszkaniami o powierzchni od $22 \mathrm{~m}^{2}$ do $75 \mathrm{~m}^{2}$. W 2009 r. powstał również budynek mieszkalny przy ul. Piwnej 25. Ponadto przy placu Bohaterów Getta 3 planowany jest 6-kondygnacyjny kompleks mieszkalny Avangarda, który pomieści 43 apartamenty o powierzchni od 31 do $148 \mathrm{~m}^{2}$.

Na rozwój obszaru wpływa również kampus KA przy ul. Herlinga-Grudzińskiego, w której w 2009 r. kształciło się ponad 15 tys. studentów (Raport o stanie miasta, 2009)5. Uczelnia oferuje kształcenie na ośmiu kierunkach studiów w systemie dwustopniowych studiów magisterskich. Absolwent w zależności od poziomu kształcenia może uzyskać tytuł zawodowy licencjata, inżyniera lub magistra. Uczelnia ma uprawnienia do nadawania tytułu stopnia naukowego doktora nauk prawnych w dyscyplinie prawo oraz do nadawania stopnia naukowego doktora nauk humanistycznych w zakresie nauk o polityce.

Na obszarze Zabłocia znajdują się również Krakowskie Szkoły Artystyczne (KSA) przy ul. Dekerta. KSA obejmuje: Szkołę Aktorską SPOT, Szkołę Artystycznego Projektowania Ubioru (SAPU), Szkołę Kreatywnej Fotografii (SKF), Szkołę Wnętrz i Przestrzeni (SWP), Szkołę Visual Merchandising (SVM). Kształcenie odbywa się w trybie dziennym i zaocznym, program obejmuje dwa lata (SPOT, SKF, SWP, SVM) lub dwa i pół roku nauki (SAPU).

\section{WNIOSKI}

W świetle przeprowadzonej analizy obszaru należy stwierdzić, iż uchwalenie MPZP i LPR Zabłocia przyczyniło się do zainteresowania tym obszarem prywatnych inwestorów, którzy obecnie są realizatorami większości inwestycji, do których można zaliczyć m.in. powstanie kampusu KA, budowę apartamentowców przy ul. Przemysłowej, ul. Piwnej, placu Bohaterow Getta, loftów w młynie „Ziarno 2”, biurowca Diamante Plaza, hotelu Cubus. Do inwestycji finansowanych z budżetu miasta zaliczyć można budowę linii tramwajowej KST oraz finansowanie budowy Muzeum Sztuki Współczesnej w dawnej fabryce Schindlera.

Analiza sfery przestrzennej Zabłocia pozwala ponadto dostrzec obiekty i obszary, które wymagają odnowy w pierwszej kolejności, lub budowy, jak np.:

- budynek dawnego magazynu solnego przy ul. Na Zjeździe 8 - wymaga remontu i przeznaczenia na nowe funkcje;

- stadion sportowy KS Podgórze - wymaga przebudowy i poszerzenia bazy sportowej;

- parking podziemny - istnieje potrzeba stworzenia miejsc parkingowych oraz parkingu. Nie ma zapisów o przeznaczeniu środków na taką inwestycję w budżecie miasta na 2010 r.;

\footnotetext{
${ }^{5}$ Uczelnia kształci studentów na 21 kierunkach studiów tj. administracji, architekturze i urbanistyce, bezpieczeństwie narodowym, dziennikarstwie i komunikacji społecznej, ekonomii, filologii, w zakresie języka angielskiego, gospodarki przestrzennej, informatyki i ekonometrii, kosmetologii, kulturoznawstwie, malarstwie, nauk o rodzinie, ochrony środowiska, pedagogiki, pielęgniarstwa, politologii, prawa, ratownictwa medycznego, socjologii, stosunków międzynarodowych, zarządzania.
} 
- modernizacja, renowacja budynków - w ramach aktualizacji LPR Zabłocia zbierane były ankiety karty projektów, celem poznania oczekiwań mieszkańców, czy podmiotów działających na tym obszarze. Zarząd Budynków Komunalnych zgłosił wówczas projekt modernizacji i renowacji budynków przy ul. Krakusa 30, Limanowskiego 30, 32, 34, Lwowskiej 4 oraz Zabłocie 9A. Inwestycja została oszacowana na $5 \mathrm{mln}$ zł. Zgodnie ze stanem na grudzień 2010 r. inwestycja nie jest realizowana;

- przekształcenie lub remont obiektów poprzemysłowych, infrastruktury oraz przestrzeni - obecnie na obszarze Zabłocia panuje chaos przestrzenny. Większość budynków i dróg nie była remontowana od wielu lat;

- pas nasypów przy przystanku PKP Zabłocie-Garden Residence po uzyskaniu odpowiednich zezwoleń planuje uporządkować nasypy i zamienić je w zielone ogrody (obecnie są one enklawą składowisk złomu oraz nielegalnych wysypisk);

- bulwary wiślane - uporządkowanie bulwarów i nadanie im funkcji;

- ścieżki rowerowe - istnieje konieczność budowy ścieżek i połączeń rowerowych z sąsiednimi dzielnicami i centrum miasta;

- zieleń - na Zabłociu jako obszarze poprzemysłowym brakuje obszarów zielonych, miejsc odpoczynku.

\section{Literatura}

Janas K., Jarczewski W., 2010, Model procesu rewitalizacji - poziom lokalny, [w:] Model rewitalizacji miast polskich, t. 10, red. K. Janas, W. Jarczewski, W. Wańkowicz, Instytut Rozwoju Miast, Kraków.

Jędraszko A., 2005, Zagospodarowanie przestrzenne w Polsce - drogi i bezdroża regulacji ustawowych, Wydawnictwo Platan, Kryspinów.

Gzell S., 2006, Uwarunkowania procesów rewitalizacji polskich miast, [w:] Problemy rewitalizacji w gospodarce przestrzennej XXI wieku, red. W. Czarnecki, Wyższa Szkoła Finansów i Zarządzania w Białymstoku, Białystok.

Lokalny program rewitalizacji Starego Miasta, 2008, Urząd Miasta Krakowa, Kraków.

Lokalny program rewitalizacji poprzemysłowego obszaru Zabłocia, 2006, Urząd Miasta Krakowa, Kraków.

Lokalny program rewitalizacji poprzemysłowego obszaru Zabłocia, 2008, Urząd Miasta Krakowa, Kraków.

Małopolski Regionalny Program Operacyjny na lata 2007-2013, 2007, Urząd Marszałkowski Województwa Małopolskiego, Kraków.

Markowski T., 2009, Karta Przestrzeni Publicznej - zasady, których trzeba przestrzegać, [w:] Nowa urbanistyka - nowa jakość życia, Materiały III Kongresu Urbanistyki Polskiej, red. E. CichyPazder, T. Markowski, Urbanista, Warszawa.

Podręcznik rewitalizacji. Zasady, procedury i metody działania współczesnych procesów rewitalizacji, 2003, Urząd Mieszkalnictwa i Rozwoju Miast, Warszawa.

Rachwał T., Świerczewska-Pietras K., 2010, Evaluation of effects of EU funds utilization for revitalization in the Malopolskie voivodeship, [w:] Regional Development and Regional Policy in Poland: First Experiences and New Challenges of the European Union Membership, Part II, eds. P. Churski, W. Ratajczak, Studia Regionalia, vol. 27, Part II, Polish Academy of Sciences, Committee for Spatial Economy and Regional Planning, Warsaw.

Raport o stanie miasta, 2009, Urząd Miasta Krakowa, Kraków.

Świerczewska-Pietras K., 2009a, Analiza sektora MSP w obszarze objętym Lokalnym Programem Rewitalizacji Zabłocia, [w:] Rola przedsiębiorczości w ksztaltowaniu spoleczeństwa informacyjnego, red. Z. Zioło, T. Rachwał, Przedsiębiorczość - Edukacja nr 5, Zakład Przedsiębiorczości 
i Gospodarki Przestrzennej Instytutu Geografii Uniwersytetu Pedagogicznego w Krakowie, Wydawnictwo „Nowa Era”, Warszawa-Kraków.

Świerczewska-Pietras K., 2009b, Inwestycje w infrastrukture informatyczna podmiotów gospodarczych działajacych na poprzemystowym obszarze objętym Lokalnym Programem Rewitalizacji Zabłocia w Krakowie, [w:] Funkcje przemystu w ksztaltowaniu społeczeństwa informacyjnego, red. Z. Zioło, T. Rachwał, Prace Komisji Geografii Przemysłu PTG, t. 13, Wydawnictwo Naukowe Uniwersytetu Pedagogicznego w Krakowie, Warszawa-Kraków.

Świerczewska-Pietras K., 2010a, Finansowe instrumenty wsparcia rozwoju przedsiębiorczości rewitalizowanych obszarów Krakowa z wykorzystaniem funduszy UE, [w:] Przedsiębiorczość w warunkach integracji europejskiej, red. Z. Zioło, T. Rachwał, Przedsiębiorczość - Edukacja nr 6, Zakład Przedsiębiorczości i Gospodarki Przestrzennej Instytutu Geografii Uniwersytetu Pedagogicznego w Krakowie, Wydawnictwo „Nowa Era”, Warszawa-Kraków.

Świerczewska-Pietras K., 2010b, Instrumenty wspierajace działania rewitalizacyjne i ich wplyw na aktywizację zdegradowanych układów przestrzennych na przykładzie Wrocławia, Lodzi i Krakowa, [w:] Procesy transformacji przemystu i uslug $w$ regionalnych i krajowych układach przestrzennych, red. Z. Zioło, T. Rachwał, Prace Komisji Geografii Przemysłu PTG, t. 14, Wydawnictwo Naukowe Uniwersytetu Pedagogicznego w Krakowie, Warszawa-Kraków.

Ziobrowski Z., 2010, Cele i efekty projektu, [w:] Rewitalizacja miast polskich jako sposób zachowania dziedzictwa materialnego i duchowego oraz czynnik zrównoważonego rozwoju. Podsumowanie projektu, red. Z. Ziobrowski, B. Domański, Instytut Rozwoju Miast, Kraków.

\section{Changes in spacial structure of Cracow's post-industrial district of Zabłocie, covered by the local revitalization programme}

Cracow's area of Zabłocie, covered by the local revitalization programme, was formed during the development of industrial plants in $18^{\text {th }}$ and $19^{\text {th }}$ century. The local business activities included the Factory of Nets, Furniture, Ferrum Constructions and Ornament Goods owned by Józef Gorecki, whose products, even today, embellish the interiors of the Old Theater, the Chamber of Commerce and Industry, or the Cracow's Soap Factory owned by Czesław Śmiechowski (currently Miraculum), which was the largest plant of this type in Krakow. The area of Zabłocie also housed the city's largest distillery plant, "Cracow Vodkas", as well as the Polish Healthy Bread Manufacture "Ziarno". After the Second World War the post-industrial Zabłocie changed its production profile from technically simple to technologically advanced goods. Gorecki's factory was replaced with "Telpod", which, following political transitions of the 1990's, was declared bankrupt.

During the political transformation as well as at the end of the nineties, Zabłocie became "the forgotten" area of Kraków. The ongoing deterioration of post-industrial buildings as well as spacial and infrastructural chaos influenced the deepening processes of the area's functional structure within the territory of the city. It was only the municipality, which objective was to bring the district out of crisis and which based its politics on passing of both local plan of spacial economy and local revitalization programme, that generated investors' interest in the area. Currently Zabłocie is undergoing revitalization works on post-industrial buildings which, thanks to new functions, can be again incorporated into the area's spacial structure. With regard to the above, the objective of this essay is to present structural changes which the district has undergone over the course of recent years and which have significantly influenced its functional transition from post-industrial to the one oriented on development of small and medium enterprises sector and housing.

dr Katarzyna Świerczewska-Pietras

Uniwersytet Pedagogiczny w Krakowie

Instytut Geografii

Zakład Przedsiębiorczości i Gospodarki Przestrzennej

e-mail: k.swierczewska.pietras@gmail.com 